\title{
Curriculum Integration and the Forgotten Indigenous Students: Reflecting on Métis Teachers' Experiences
}

\author{
Carmen Gillies
}

\author{
University of Saskatchewan
}

Author's Note

Carmen Gillies ORCID ID: https://orcid.org/0000-0002-1903-1670

Correspondence concerning this article can be directed to Carmen Gillies at carmen.gillies@usask.ca

\begin{abstract}
Curriculum integration, or in other words, changing what students are taught within racially desegregated Canadian schools, has served as a primary but incomplete pathway to racial justice. In this paper, I present evidence from a qualitative critical race theory (CRT) methodological study with 13 Métis teachers to demonstrate how curricular integration has been framed as a key solution to inequitable outcomes concerning Indigenous students. This strategy has been instilled within the Saskatchewan K-12 education system by a wide spectrum of authorities over several decades. Although absolutely essential for multiple reasons, I argue that teaching students about Indigenous knowledge systems and experiences, as well as anti-racist content, cannot resolve the systemic racial injustices encountered by Indigenous students who attend provincial schools. In particular, three CRT analytical tools - structural determinism, anti-essentialism, and interest convergence - are utilized to examine the limitations of curricular integration as a strategy of racial justice.
\end{abstract}

Keywords: Métis teachers; Indigenous education; critical race theory; integrated schools 


\section{Curriculum Integration and the Forgotten Indigenous Students: Reflecting on Métis Teachers' Experiences}

In his book, And We Are Not Saved: The Elusive Quest for Racial Justice, Derrick Bell (1987) discussed the dangers of taking a narrow view for school-based racial integration. To introduce his argument, Bell told a fictional counter-story entitled, "Neither Separate Schools nor Mixed Schools: The Chronicle of the Sacrificed Black Schoolchildren," which is a tale about the first day of American desegregated schooling in a community where White families and, for different reasons, some Black families had opposed student integration. In spite of community trepidation, desegregation policies proceeded and the first day of racially integrated schools finally arrived. On that first day of integrated schooling, however, to the horror of Black families, all the Black schoolchildren disappeared. At first, many White community members felt the disappearance was "for the best" given the presumed dismal conditions in which Black children lived, the assumed inability of Black students to compete with White students, and the belief that Black students would diminish the status of schools attended previously only by White students. Once White community members and school authorities grasped what would be lost without the Black students, such as funding and employment opportunities stipulated for integrated schools, increased effort was put into locating the children. Sadly though, soon enough, "all the community came to realize the tragedy's lamentable lesson. In the monumental desegregation struggle, the intended beneficiaries had been forgotten long before they were lost" (Bell, 1987, p. 107).

Bell (1987) told this allegorical counter-story to stress how the American 1954 Brown v. Board of Education school desegregation law, a monumental civil rights achievement, did not lead to the desired outcomes. As critical race theory scholars have argued, the physical integration of Black and White students did not eliminate the White supremacist foundations of the American education system (Irvine, 1988; Leigh, 2003; Taeuber, 1990). While Black segregated schools were underfunded, under-resourced, and lacking credentials afforded to White schools, the schools were also governed by Black authorities and teachers who determined the curriculum and invited parental input. Further, Black students did learn about Black history and culture in segregated schools. Conversely, American state school integration policies did not ensure that Black children would receive quality care, nor a meaningful, rigorous, and equitable education. Therefore, although Black civil rights advocates and communities had fought for and demanded desegregation, racially integrated schools did not protect Black students from institutionalized racism.

Furthermore, White citizens benefitted from numerous school integration policies. Integration policies enabled White authorities to close Black, not White, segregated schools, to demote Black administrators, replace Black teachers with White teachers, and force Black students to bus to White communities, which often resulted in White residents fleeing to predominately White communities (Irvine, 1988; Taeuber, 1990). In addition, resources were not distributed equitably within schools and Black parents and professionals were not consulted (Ladson-Billings, 1998; Taylor, 1999). As a result, Black students were moved from Black segregated schools to endure racist learning and social environments and a White normative curriculum taught primarily by White teachers who systemically held racist beliefs (LadsonBillings, 2011). In this way, as Bell (1987) explained, the interests of Black students were lost or "disappeared" in the pursuit of desegregation. 
Bell (1987) did not argue for a return to segregated schooling. Instead, his work revealed why comprehensive racial justice cannot be achieved in racist societies through restrictive or narrow approaches. Mandating the physical integration of racialized student bodies could not lead to racial justice because it is in the interests of even well-meaning White citizens to ensure racial equality remains elusive - as observed by Bell (1987). Marked by the 1954 Brown $v$. Board of Education case and the 1961 Affirmative Action ruling, the civil rights movement did improve the socio-economic standing of African Americans for nearly two decades, but poverty and unemployment reached levels higher than those prior to the Brown decision by the 1980s (Bell, 1980; Freeman, 1988; Hardwick, 1991). Gains achieved by civil rights litigation, including school desegregation laws, have, therefore, not led to the anticipated results but rather, through numerous systemic means have consolidated advantaged onto White citizens (Ladson-Billings, 1998).

Inspired by Bell's (1987) analysis, I argue that mandating Indigenous curricular integration within desegregated Saskatchewan schools has also not led to the desired outcomes and, as such, broader institutional and systemic approaches are needed. Indigenous-First Nations, Inuit and Métis - and non-Indigenous students in Canada are no longer separated through historical racist policies of segregated schools, yet the subordination of Indigenous students enrolled in, and attempting to attend, provincial $\mathrm{K}-12$ integrated schools persists. The primary pathway proposed to counter this subordination, however, has remained almost exclusively fixated on what and how students are taught even as racial inequities endure. To present this argument, I center Métis people and Saskatchewan schools. First, I outline a brief historical review of Métis experiences with Saskatchewan schools. I then present qualitative evidence from a critical race methodological study with 13 Métis teachers to demonstrate how the provincial curriculum remains a pressing focal point when considering racism within Saskatchewan desegregated schools. To conclude, I extend my argument to discuss why curricular integration on its own is an incomplete solution to transcending institutionalized racism and colonial hierarchies within education systems.

\section{Saskatchewan Métis Experiences}

The Canadian government recognized Métis as Indigenous people officially in the 1982 Constitution Act under section 35(2). Noting ongoing debates regarding Métis citizenship and identity criteria, scholars agree that Saskatchewan Métis communities originated from the expansion of the fur trade into Western Canada from the late 1700s until the late 1800s (Chartrand, 2006; Macdougall, 2012). Because Canada's historical economy depended on the fur trade, unions between primarily British, French, and Scottish men and First Nations women were for a time encouraged by colonial governments (Van Kirk, 1980) and such unions led to culturally distinct Métis/Michif communities (Macdougall, 2012). Unlike Indigenous peoples, such as First Nations and Inuit who were constructed as racially pure, however, in-line with racial ideologies of the time (Young, 1995), British and French colonial, and later Canadian, officials constructed Métis as mixed-race. The presumed biological and moral innate inferiority of so-called mixed-race people was authorized through scientific racism and Western institutions until after World War II (Willinsky, 1998) and, in Canada, were used to legitimize the oppression of Métis people. Thus, colonial imposed practices of dispossession and terror, of which Métis resisted diplomatically and through military force, were sanctioned by the racialization of Métis as mixed-race. 
Racialization processes occurring throughout Saskatchewan's history have shaped the formal educational experiences of Métis families beginning with fur trade company schools. Littlejohn (2006) explained that Métis and First Nations children could attend Hudson Bay Company (HBC) schools from the 1820s until 1869 when the HBC sold Rupert's Land to the Government of Canada. The HBC schools were run by missionaries who sought to "civilize" half-breeds and First Nation children to encourage HBC employee commitment. Missionary schools excluded parental input, and thus "parents had no say in how the schools were administered or what the curriculum would include" (Chartrand, 2006, p. 15). Furthermore, "the non-participation of parents in the education system left children vulnerable when emotional and physical abuse occurred or when students were exposed to incompetent teachers" (Chartrand, 2006, p. 16).

In 1870, after the HBC sold Rupert's Land to Canada and as Canada negotiated numbered treaties with First Nations as a strategic colonial strategy to secure access to, and control of, land and resources, education policy concerning Métis and First Nations children took different directions. The Federal Government gained control of HBC missionary schools and thereafter funded only First Nations students as promised in treaty negotiations and legalized in the 1876 Indian Act. Although some Métis children attended Federal residential schools with First Nations students in the newly formed North West Territories, Métis students were often considered outsiders (Chartrand, Logan \& Daniels, 2006). In addition, because the Federal government would not fund Métis students, Métis families were forced to pay for their children to attend residential schools and often only Métis children deemed "uncivilized" or who spoke Indigenous languages were accepted for enrollment (Littlejohn, 2013). Eventually, residential schools only accepted Métis students when First Nation student enrollment quotas were not filled (Littlejohn, 2006).

While several Métis communities established schools and school boards beginning in the late 1800 s, such positions of authority were displaced with the gradual arrival of White settlers after 1905 (Littlejohn, 2013). Barriers to provincial schools attended by White settler children, however, also existed as the schools were "funded through local property taxes. Since most of the Métis parents lived in road allowances or Crown lands, they did not pay taxes" (Littlejohn, 2006, p. 73). Therefore, Métis who did not pay property taxes were not eligible to send their children to provincial schools with White settler families. In addition, White provincial schools in southern Saskatchewan often refused to admit Métis students. Barron (1990) explained, "Native parents had been discouraged from sending their children to schools. The excuse commonly cited was that Native children represented a health hazard, a fact under-scored in a 1943 school report... In reality, the health issue was little more than a smoke-screen for racial and class prejudice" (p. 246). Consequently, some Métis families who could identify as White did so to avoid racial persecution and gain access to provincial schools as well as other institutions.

Métis exclusion from provincial schools continued until the Co-operative Commonwealth Federation (CCF) was elected in 1944 and took direct action through multiple policies (Anuik, 2010). The CCF's political move mirrored the 1950s national desegregation policies which culminated in the gradual closure of residential schools. In spite of the turn toward racially integrated provincial schools, Métis students, like Black American students after the 1954 Brown decision, continued to experience inequitable K-12 outcomes. Ensuring all Métis students have access to quality provincial education has remained a long and pressing necessity. For example, CCF Métis education programs in northern Saskatchewan were rarely successful and throughout 
Saskatchewan Métis students were provided a modified education. In the 1970s, a three-part plan was implemented by the Saskatchewan government to study "the 'deficiencies' of Métis learners and their families; investments in schools; and solicitation of evidence-based expert opinions from teachers and scholars on effective pedagogy and curriculum for Métis learners" (Anuik, 2010 , p. 83). Such policies were grounded in racist ideology that viewed Métis families as problems that could be "fixed." Métis students have been excluded from, or forced to attend often racially hostile, integrated schools that have yet to lead to socio-economic prosperity on par with the White Saskatchewan population. Yet, throughout each stage of segregation and integration, Métis have resisted oppressive conditions and fought for equitable and culturally affirming education.

\section{Critiques of Cultural Integration}

Responding to inequitable outcomes derived from racist school policies and practices such as those experienced by Métis students, calls to Indigenize educational curricula within integrated schools have been championed by Provincial and Federal Governments. This activism has been brought to the forefront of policy discussions by Indigenous leaders, scholars, and educators and has led to multiple progressive culturally responsive provincial Indigenous education policies. In particular, in 1989 the Saskatchewan Ministry of Education directed all teachers to integrate Indigenous content across subject areas and grade levels and in 2010 Treaty education was mandated. Although the 1989 directive was not enforced initially, multiple supplementary Ministry documents have since been released and school divisions and teacher education programs across the province, in varying capacities, now aim to prepare all teachers to meet this goal. Increasingly, First Nations, and to a lesser extent Métis/Michif, language programs and cultural initiatives have been integrated within Saskatchewan school divisions.

According to Lentin (2005), Indigenous peoples' demands for culturally responsive education as a primary solution to educational racial inequality can be traced to the United Nations' Educational, Scientific, and Cultural Organization's (UNECSO) The Race Question. Released in 1956, after WWII, The Race Question featured renowned scientists who disavowed two centuries of institutionalized scientific racism. Since this time, as Lentin (2005) argued, "the culturalist approach epitomized by the UNESCO tradition has dominated ideas about how to interpret and propose solutions to racism in the post-war western world" (p. 389). Lentin (2005) further explained,

Culturally based explanations of human difference and culturalist solutions to racism emerged out of an elite project, piloted by the United Nations and legitimized by renowned academics. To blame the racialized for the culturalization of politics and the resultant depoliticization of anti-racism is to misunderstand the origins of the culturalist project and to disregard the choice often faced by black and "minority ethnic" anti-racists, from the 1980s on, between adopting the language of multiculturalism or ceasing to be socially and politically engaged. (p. 390)

Lentin's argument holds true in Saskatchewan where Métis demands for provincial funding were upheld in the late 1970s, which led to an apparent strategic turning away from Métis critiques of White supremacy and colonialism, such as those of Howard Adams, in the 1980s. With this shift in policy, a gentler cultural integration discourse took precedence. For example, the Métis grassroots political activism magazine New Breed called for radical transformation and Métis rights, often challenging racism, throughout the 1970s (Bird-Wilson, 2011). The tone of New 
Breed, and Métis activism in general, changed considerably - toward a language of cultural revitalization-with provincial government funding stipulated to Métis organizations in the 1980s, even as Métis injustices endured.

At the same time, White society in general did not immediately accept even a liberal cultural approach to integration within Saskatchewan schools. Indeed, cultural education as a solution to racial inequity in $\mathrm{K}-12$ schools has slowly, over the past few decades, gained legitimacy and acceptance within Saskatchewan's White population. Noting this acceptance as a positive step forward, but also the marginal change occurring through cultural integration initiatives, beginning in the mid-2000s anti-racist Indigenous education scholars published critiques of cultural education in Saskatchewan schools (Comeau, 2005; Gebhard, 2017; McCreary, 2011; St. Denis, 2004; 2007; 2009; 2011). Building on Canadian and American antiracist theory, critiques of cultural education deconstruct discourse that situates cultural differences rather than racism as the cause of racial inequities.

Critiques of cultural education, therefore, also contest the assumption that equitable $\mathrm{K}-12$ outcomes can be achieved when Indigenous students are taught their cultural identity or learn in culturally affirming environments. Leonardo (2014) argued that "culturally relevant education for students of colour, which is defined as one that resonates with and is sympathetic to their meaning systems, by itself is not enough [to achieve racial justice], especially if it happens within broader conditions of racial inequality" (p. 35). Moreover, strengthening Indigenous students' sense of identity does "little to ensure that white teachers will view their [Indigenous] pupils as capable of the same level of achievement and range of desires as their white students" (Razack, 1989, p. 9).

As Yosso (2005) noted, "Race is often coded as 'cultural difference' in schools" (p. 175). In this way, teachers argue it is not the biological racial deficits of students that act as barriers to success - as this would be viewed as racist - but rather the culture of non-White students prevents academic achievement. Ladson-Billings (2006) further explained that deficit thinking is embedded within "cultural difference" language, arguing: "[Teachers] use it with authority as one of the primary explanations for everything from school failure to problems with behavior management and discipline" (p. 106). This is certainly the case in Saskatchewan where culturally responsive discourse remains prevalent as an accepted strategy of equity and decolonization. Yet, graduation rates have changed little in spite of this discourse stressed within multiple Ministry and division policy papers over several decades. Furthermore, as the findings of this study suggest, Indigenous curricular integration itself has not materialized at wide-scale systemic levels.

\section{Gathering Data}

A qualitative critical race methodological (CRM) study with 13 Métis Saskatchewan teachers informed the findings. CRM is grounded in critical race theory (CRT) and was selected to frame this research with Métis teachers because it explicitly names White supremacy as endemic and values the experiential knowledge of racially oppressed people. Furthermore, CRM works to uncover and challenge racialization processes in institutions such as $\mathrm{K}-12$ education systems. Originating from rich multifaceted intellectual histories of resistance to White supremacy and colonialism, critical race theory emerged from American legal scholars of colour and White allies in the 1980s in response to the arrested success of civil rights movements (Bell, 1992). 
CRT materialized as legal scholars examined the limitations of civil rights litigation and was first applied to the field of education with Ladson-Billings and Tate's (1995) seminal work.

Within critical race methodology, research methods and analyses must align with particular CRT tenets (Dixson \& Rousseau, 2005). First, CRT asserts that racism and White supremacy are endemic to society. Skepticism of liberalism is the second CRT tenet and includes critiques of race neutrality, colour-blindness, individualism, meritocracy, and post-racialism. Acceptance of racially oppressed peoples' experiential knowledge or counter-stories as valid and legitimate is a third CRT tenet. Fourth, CRT necessitates that research is situated within a "history of racial subordination" (Parker, 1998, p. 45) and thus critiques ahistorical analyses. Fifth, CRT scholars assert that racial justice can and must counter all systems of intersecting oppression. And last, CRT is necessarily interdisciplinary by embracing various theories that further the cause of racial justice in specific contexts. Critical race methodology also requires that the research is situated in CRT through the use of CRT analytic tools. In this study, structural determinism, anti-essentialism, and interest convergence are utilized to analyze the findings.

I used the snowball method (Marshall \& Rossman, 2011) to recruit Métis teacher participants who accepted an invitation that stated clearly the intent of this critical race research. Nine of the participants can pass as White and four are visibly Indigenous with darker skin tones. All of the participants identify openly as Métis and ranged from beginning teachers to those with decades of experience. Each participant answered a series of questions regarding their experiences with racism as $\mathrm{K}-12$ students and teachers. To gather robust data, I interviewed each participant for approximately 90 minutes using the conversational method (Kovach, 2010). I selflocated with participants as a Métis anti-racist educator and explained the purpose and intention of the research from my subjective position. Data were analyzed using an iterative approach and NVivo software until primary themes were identified through memoing (Charmaz, 2006) and systematic procedures including open, axial, and selective coding (Boeije, 2010; Saldana, 2009).

\section{The Findings}

The following section has arisen from a larger study in which I examined Saskatchewan Métis teachers' experiences with racism. Uncovered through the research, Métis teachers' school-based experiences are shaped intergenerationally by unique histories of institutionalized colonial processes including Saskatchewan's segregated and integrated schools. The findings presented are, therefore, situated within historical patterns of racism - the ideological system that upholds and normalizes colonialism, systemic racial violence and inequities, and White supremacy. For the purpose of this paper, I present four primary themes identified within the 13 Métis teacher participants' discussions concerning barriers to teaching Indigenous knowledge, history, and experiences, as well as anti-racist education to $\mathrm{K}-12$ students.

\section{Barriers to Curricular Integration}

When answering the question, "Please tell me some stories about how you have experienced and witnessed racism as a teacher," the participants' answers varied but included a wide spectrum of examples. In general, even those teachers who could pass as White held critical perspectives or a partial awareness of racism as systemic, connected to historical colonization processes, and benefitting White identified citizens. While the participants were able to name multiple ways in which racism disadvantages Indigenous students, the importance of teaching 
meaningful Indigenous culture, decolonized history, and anti-racism content was stressed repeatedly as key to challenging racial inequities.

In general, the participants were not taught about Indigenous people, knowledge, nor experiences when they attended Saskatchewan K-12 schools. While some graduated from provincial high schools in the early 2000s and others as early as three decades prior, each participant shared similar experiences with limited Indigenous classroom content. Some remembered learning about Indigenous culture through indirect inferences, such as the following:

I recall when I was in Grade 6 or 7 ... We went snowshoeing, we cooked out on the open fire, and things like that. I sort of felt that I identified with it. But, I don't recall anything specifically being taught about First Nation or Métis in the schools. (P11)

Other participants recalled being taught superficial dehumanizing messages such as, "In elementary school, they had the alphabet on the wall. I remember [for the letter] 'I' they had a picture of a headdress and it said Indian" (P7). Several participants remembered being taught about "Louis Riel the traitor ... back when words like 'savage' were very prominent in textbooks ... and so the slant on history was very [racist]" (P8). Participants who did not grow up knowing they were Métis but knew they were Indigenous, due to historical colonial processes, found the limited Indigenous content they were taught contributed to a false identity. One participant explained, "I had an Aboriginal teacher in Grade 4 and we sang this song in Cree and I remember thinking, "I think I am Cree"” (P9).

Indigenous Studies while attending high school was also not an option for most of the participants. As one participant recalled: "I don't remember any of it [until my sibling took it], so 2011 was the first time they offered Indigenous Studies" (P1). While some participants did learn about Indigenous history, this content was not presented through an anti-racist lens as described by another participant:

We watched a video on the Beothuk and their extinction, and we had to answer a question, was it genocide? And that started my thinking. I didn't have the word colonization. I didn't have that knowledge yet, but it started my thinking that there was some injustice inflicted on people when Europeans started to come over. (P5)

More meaningful decolonized content taught by some teachers rarely focussed on Métis peoples as "there wasn't much of a Métis focus in Native Studies in high school" (P6).

Given the participants as students were generally not taught Indigenous content, and that curricular integration is stressed at every level of the $\mathrm{K}-12$ system as a primary means in which to increase Indigenous student graduation rates, barriers to curricular integration were recurring themes in the data. Specifically, four themes were identified: individual teachers who refuse to teach Indigenous content, fractured approaches to Indigenous curricular integration, the objectification of Métis teachers as cultural experts, and systemic fear of anti-racism education.

\section{Refusal of Individual Teachers}

Overall, the participants acknowledged that Indigenous education is prioritized to a greater degree than when they attended $\mathrm{K}-12$ schools and some participants had worked at schools where Indigenous curricular integration was embraced. Participants in general, however, 
also spoke about encounters with teachers who chose not to integrate Indigenous knowledge and experiences. As one participant stressed, "Even though the curriculum has changed ... I really question if it is being taught in all the schools in all the classrooms and why not, yet it is mandated" (P11). One reason why curricular integration has not been realized fully, according to the data, is that "there's a little bit of push back to the expectation and [teachers] are feeling like they are being harped on that they have to [integrate Indigenous content]" (P3). For example, one participant witnessed a high school administrator state, "Province-wide results [on standardized Treaty teachings] were awful [and] reserves' results were awful ... If [First Nations students] don't know it, why should we have to know it, why should we have to teach it" (P5). In the same way, another participant commented, "With teaching Treaties in the classroom as a requirement, you see a lot more uneasiness about who [teachers] are when it comes to non-Aboriginal teachers" (P7). Consequently, mandating Indigenous curricular integration has been perceived by some teachers as infringing on the rights of individual teachers. This finding is congruent with research that has examined White teachers within multiple contexts (Castagno, 2009; Stoll, 2014; Vaught, 2012).

Moreover, according to the interviews, some White teachers perceive the act of Indigenous curricular integration as a special right granted to Indigenous students denied to other students. For instance, participants stressed that White teachers have argued, "Why are we even doing all this [First Nations, Métis, and Inuit] stuff anyway, why are we talking about the Native students all the time?" (P10). As another participant stated, "There were teachers and educational assistants who thought we should not just focus on Aboriginal students because we had kids from Burma and all over the place" (P8). Another participant shared a story about teaching at a school that values Cree knowledge systems, saying, "[A teacher at a staff meeting] was saying why would we have a Cree influenced value system when there are so many other cultures?" (P12). Fortunately, at this particular school, a majority of the staff rejected this teacher's position, but this was not reported as common by most of the participants. Rather, the data indicates that schools continue overwhelmingly to operate as White normative spaces and teachers can choose to disregard Indigenous curricular outcomes and provincial mandates at their discretion.

\section{Objectifying Métis Teachers}

Barriers to Indigenous curricular integration was also identified through the Métis teachers' experiences of being positioned as cultural experts. One participant shared,

I have felt that everyone's shoulder tapping me for something because "we need an Aboriginal person for this thing." I also have often felt that I am being used to tick a box. I have actually once said, you know what, I am just myself and I do not represent all Aboriginal people, I don’t represent all Métis people. (P10)

This finding is replicated in research with other racialized teacher populations who reported feeling pressure to act as cultural resources for White colleagues and to sit on numerous committees as cultural representatives (Jay, 2009; Reid \& Santoro, 2006; St. Denis, 2010).

Another participant who worked with a school division's Indigenous education unit had been told, "Well you are working with the brown team so you clearly have some sort of Aboriginal in you, so you must speak Cree and you must know this and you must know this." (P9). The expectation that all teachers must teach Indigenous content thus often falls upon the 
small number of Indigenous teachers who are objectified through pan-Indigenization or assumptions that Indigenous teachers must know everything about all Indigenous people. Indigenous teachers then face pressure to provide culturally relevant support to White teacherswho comprise approximately $90 \%$ of the provincial teaching force-without financial compensation. The data indicates that Indigenous teachers are often asked to find culturally appropriate resources and build relationships with Indigenous students and communities on behalf of White teachers. Such requests are made regardless of the Indigenous teacher's cultural identity. One Métis teacher described,

I have to be the First Nation person because if anyone wants to know anything First Nations, they come to me and I don't know. So, I have to educate myself, right? So, of course I have to do pow wow too, so I have singers and drummers. (P6)

At the same time, many participants felt a responsibility as one of a few Indigenous or the only Métis teacher on staff to ensure Indigenous content is taught to students.

\section{Fractured Approaches}

Another barrier to curricular integration, according to the data, occurs through fractured approaches when teachers pick and choose various lessons about Indigenous people but do not provide substantial comprehensive knowledge. Fractured approaches include tokenistic or surface level instruction. According to most of the Métis teachers I interviewed, when teachers do teach Indigenous content, this practice is often reduced, perhaps unintentionally, to tokenism as has been found in studies within varying racialized contexts (Chandler, 2009; Hollingworth, 2009; St. Denis, 2010). For instance, one participant stressed,

These new math textbooks that have the odd question thrown in about, "Denise is part of a traditional singing group, she is making a new drum, the circumference is this, calculate how much hide she is going to need." Give me a break. (P10)

As such, participants underlined a need to teach students about Indigenous culture, history, and rights in more meaningful, decolonized ways.

Fractured approaches also include non-threatening lessons and field trips that serve to comfort or entertain non-Indigenous teachers and students. For instance, as one teacher shared, "No one really wants to know who [we] are-they want to be able to say, oh this is delightful" (P2). Another participant explained, "We do the dance and cultural stuff really well. Do we do the historical identity piece as much, maybe not" (P1). As another participant stressed,

We want to talk about the values and the medicine wheel, and we do smudging and run a drumming group, so we want those positive things but we are not talking about colonialism and figuring it out and making sure everyone understands. (P12)

Thus, culture becomes entertainment through approaches that advance only certain knowledge. For instance, "The sweats that [schools] have and pow wows are all First Nations events and I think First Nations are a little more exotic than Métis and get a little more press and excitement" (P3).

Consequently, fractured approaches were identified as adversely impacting Métis education. One participant expressed frustration, saying, "Treaties are mandatory, well what's mandatory for Métis history? Our Métis communities have been really fighting for that for a long 
time. So how is it even possible that it's still left out? (P1). Another participant pointed out, "It is frustrating but confusing to me that we focus on Treaty 6 and Cree culture. That makes sense to an extent but then we also have Métis kids and our Métis population" (P9). Embracing the responsibility to teach Métis culture, the participants also explained how "sometimes you have to veer away from your curriculum a bit and make sure that when kids pass through your classroom, they pass through gaining the knowledge of the history of Aboriginal people in this country" (P8). In general, the participants emphasized a need to interrupt fractured approaches to Indigenous curricular integration by prioritizing anti-colonial recognition and understandings. As one participant shared, "Talking about jigging and food, [is] part of who we are, [but] there's so much more in the spirit of our people - our sense of resistance, our sense of doing what is best for our community" (P1).

\section{Fear of Anti-Racism}

Reflecting anti-racist critiques of cultural education, many of the participants stressed that while some teachers may teach anti-colonial education, even fewer teachers teach about White advantages, structural racism and intersectional oppression. As one participant explained,

[The common approach] only brings [Indigenous] people's cultural beliefs to the forefront and other people can learn from it-about the peace pipe, about pow wow, about certain ways that young people might dress in regalia for a certain dance. It doesn't bring any social action; it doesn't bring any transformation. It only brings in [that] we need to learn their history; this was their land. We need to bring that into children's mindsets, where Aboriginal people came from. We need to honor the treaties. We need to teach about residential schools. It's mandated now with the Provincial Government. But then it stops there. (P2)

Overall, most participants understood that, "in terms of doing a power analysis and looking at racism and colonization ... most [teachers] would get their backs up" (P5). Another participant reiterated, “[Racism] doesn't necessarily get looked at as much because people don't want to feel any fault or any blame" (P2). This finding is consistent with literature that exposes how the comfort of White identified teachers often takes precedence to teaching students about, and how to counter, ongoing racism (Buehler, 2012; Castagno, 2008; Yoon, 2012).

While most participants stressed that non-Indigenous students must be taught anti-racism perspectives of Indigenous experiences to achieve equity and justice, one participant specifically stressed why Indigenous students deserve to learn about racism and intersecting systems of oppression, stating, "They don't understand the system that keeps them oppressed" (P1). Furthermore, another participant who has worked with a division's Indigenous education unit explained, "Nobody, nobody has a degree in [anti-racism with the school division]. I would not feel comfortable teaching a group of adults how to properly [teach students about racism] because I don't believe that I even have the knowledge" (P9). Acknowledging curricular change has occurred, participants in general understood that "there are still hidden things in the curriculum, but it is not as blatant as it was. I don't know if you get away from it in Saskatchewan. I don't know if you get away from racism” (P8).

\section{Discussion}

Anti-racist critiques of cultural education appeared to influence most of the Métis teachers I 
interviewed. Reflecting on intergenerational experiences with racism in Saskatchewan schools, the participants were also able to recognize various ways in which racism disadvantages Indigenous students. Yet, how to resist and change specific racist $\mathrm{K}-12$ practices and policies at an institutional level beyond curricular integration remained elusive when analyzing the data. Expanding on curricular integration is, therefore, essential in Saskatchewan for two primary reasons. First, provincial curricular integration mandates and goals have yet to materialize in most Saskatchewan classrooms in spite of multiple Ministry directives and, second, the province's aims and goals have not led to K-12 racial equity.

That said, even if every Saskatchewan teacher integrated meaningful Indigenous knowledge, experiences and perspectives reflecting every Indigenous nation in culturally appropriate ways, and anti-racist teachings into every $\mathrm{K}-12$ classroom, it is conceivable that inequitable student achievement could persist. Lynn and Jennings (2009) explained, "Teachers who affirm the culture of their students and fail to oppose unequal school policies or speak out against unfair social policies illustrate a kind of passiveness that is necessary for a White supremacist patriarchy to thrive" (p. 192). The following discussion extends the participants' common experiences as Métis teachers to a broader context concerning Indigenous education and integrated schools. Three CRT analytical tools are utilized to frame the discussion: structural determinism, anti-essentialism, and interest convergence.

\section{Structural Determinism}

Stated previously, in 1989 Saskatchewan directed the integration of Indigenous focused content into all $\mathrm{K}-12$ schools as a response to political pressure and racially inequitable academic achievement rates. Thirty years and multiple similar policy documents later, curricular integration in Saskatchewan's provincial schools has not led to the desired results. Nevertheless, the need to integrate meaningful and epistemologically sound Indigenous knowledge systems, languages, and pedagogies within $\mathrm{K}-12$ schools continues to be stressed as a primary solution to racial inequality at a national level (Truth and Reconciliation Commission of Canada, 2015). Structural determinism is a CRT analytical tool that can assist with understanding why Indigenous education policies supported by the Ministry remain relatively unchanged in spite of a lack of progress.

Delgado and Stefancic (2012) explained that oppressive conditions are determined through recirculating pre-existing institutional language, rules, and categories that mask, distort, or minimize oppressive conditions and, therefore, predetermine specific outcomes. Exposing processes of structural determinism is a necessary process because "our system, by reason of its structure and vocabulary, is ill equipped to redress certain types of wrong" (Delgado \& Stafancic, 2012, p. 31) and thus "allow[s] the current system to replicate itself" (Tate, 1997, p. 222). This process occurs because "[education] does not merely reflect race as an external phenomenon; [education] and [educational] doctrine constitute an ideological narrative about what race and racism are" (Harris, 2002, p. 1216). As a result, as Tate (1997) argued, "One implication of structural determinism is that it limits how individuals and society at large are able to analyze and critique oppression" (p. 224). For instance, CRT legal scholar Delgado (1984) found "the twenty leading law review articles on civil rights" (p. 561) were authored by White males who cited each other. Consequently, prominent ideas and language circulated through civil rights journals determined the practices and laws deemed legitimate in civil rights litigation. In 
education, as with the legal system, "whiteness is operationalized through the messages that are sent about what is fair, equal, and equitable" (Castagno, 2008, p. 323).

According to Internet and library searches, curricular integration or, in other words, changing what and how students are taught, has habitually been recirculated as fair, equal, and equitable within a majority of Indigenous education publications and provincial Ministry policy documents produced over the past three decades. Consequently, within K-12 education, "race equity has constantly to fight for legitimacy as a significant topic for education policy makers. This is a key part of the way in which education policy is implicated in [institutionalized racism and, hence,] White supremacy" (Gillborn, 2005, p. 493). The institutional focus on curricular integration as a primary solution to racial inequality has in this way structurally determined how racism is conceptualized by $\mathrm{K}-12$ educators and thus countered within schools.

Reflected in the interviews I conducted with Métis teachers, challenging K-12 racism encountered by Indigenous students relies almost exclusively on changing what (and how) students are taught. According to a structural determinism analysis, the inability to meet curricular integration institutionalized goals, and the recurring focus on curriculum integration as a solution to racial injustice, leads to continued effort to meet such goals to the exclusion of other solutions. Narrow visions of racial justice are thus not caused by individuals but are structurally determined through the recirculation of institutional practices and vocabulary that limit the abilities of even advocates and allies to conceptualize and enact more effective ways to counter systemic racism.

\section{Anti-Essentialism}

Anti-essentialism is another CRT analytical tool that can assist with understanding why curricular integration as a primary solution to inequity is an ineffective solution. According to Ladson-Billings (2012), "Critical race theory scholarship decried essentialism. Essentialism is a belief that all people perceived to be in a single group think, act, and believe in the same things in the same ways" (p. 40). For example, essentialist beliefs concerning Métis insist authentic identities consist of speaking Michif, being involved in community, and practicing traditional culture. Based on historical analyses, CRT scholars refute such views and defend racial and cultural identities as fluid and shifting while interacting with oppressive socio-economic processes. While the need to preserve and maintain Métis culture due to colonialism is urgent, curricular integration informed by essentialist understandings of culture can lead to fractured approaches to teaching and shoulder tapping Métis teachers, who are assumed to be cultural experts, as identified in the findings.

Essentialist notions of culture also inform false assumptions that Indigenous students cannot learn nor benefit from Western knowledge or non-Indigenous epistemologies. Consequently, it can then be argued that teaching Western knowledge to Indigenous students is an oppressive act of assimilation. Such assumptions are premised on essentialist understandings of human biology that insinuate Western knowledge somehow contaminates the supposed cultural purity of Indigenous identities which leads to student failure. Unfounded essentialist beliefs that knowledge is derived from racially pure populations and passed on biologically through innate traits, also informs teachers' low expectations for Indigenous students. As Ladson-Billings (2006) argued, teachers are taught to perceive culture as, "that exotic element possessed by 'minorities.' It is what it means to be nonwhite. It is also the convenient explanation for why some students cannot achieve success in the classroom” (p. 107). When 
teachers believe Indigenous students lack abilities to learn from Western knowledge systems, this can then excuse poor teaching, which leads to poor academic performance and ongoing systemic inequities. For instance, Standard English literacy is a requisite to social and material power in Canada and at a global level. Denying Indigenous students access to high-quality Standard English literacy instruction, as several Métis participants in my study experienced as children, therefore, structurally determines inequitable outcomes. This process is a continuation of historical systems such as residential schools that claimed to assimilate Indigenous students yet offered a substandard education with the goal of creating an indoctrinated and colonized working class (Littlejohn, 2006).

Furthermore, essentialist conceptions of knowledge posit all Western knowledge (or what is assumed to be originating from White Western paradigms) as oppressive and all Indigenous knowledge as purely good or benign. Such false binaries limit potential to draw from emancipatory knowledge derived from Western paradigms and to counter oppressive practices within Indigenous epistemologies. Just as it is oppressive to construct Indigenous knowledge as inferior, there is danger in constructing Western knowledge as entirely oppressive. This line of binary thinking is similar to that of White nationalists who claim all Western journalists and scientists cannot be trusted, that all Western institutions are corrupt, and that those who make inauthentic claims of non-White identities, even unknowingly, deserve public humiliation. As a result, essentialist binary approaches to Indigenous and Western knowledge curricular integration lead to fundamentalist thinking and practices (St. Denis, 2004). When considering Métis education, as highlighted in the data, this line of thinking further excludes knowledge and experiences that do not fit neatly within racial binaries such as Métis intellectual, cultural and experiential knowledge.

\section{Interest Convergence}

The interest convergence principle, theorized by critical race theorist Derrick Bell, can also assist with uncovering the limitations of curricular integration in achieving racial justice. According to Bell's (1980) interest convergence principle, the rights of Indigenous, Black, and people of colour are only granted by the dominant White population when these rights converge with the interests of White citizens. Referring to the Brown decision, Bell (1980) argued Black Americans had fought for desegregation for 100 years, yet these demands were not considered seriously until "whites in policy making positions [were] able to see the economic and political advances at home and abroad that would follow abandonment of segregation" (p. 524). For instance, the closure of Black segregated schools presented nationwide employment opportunities for White citizens. Moreover, in America, school desegregation law converged with the interests of White society by assuming an appearance of moral authority during the cold war (Dudziak, 1998). Similarity, Raptis and Bowker's (2010) historical research has revealed Canadian school desegregation occurred largely because the federal government could no longer finance residential schools.

According to the interest convergence principle, it is practical to conceptualize racial justice strategies in ways that converge with White society's interests. Ladson-Billings (2012) explained,

We cannot expect those who control the society to make altruistic or benevolent moves towards racial justice. Instead, civil rights activists must look for ways to align the interest of the dominant group with those of racially oppressed and marginalized groups. (p. 38) 
At the same time, the interest convergence principle assists with disclosing why solutions accepted by a majority of White citizens concerning what is needed to achieve justice, rarely, if ever, lead to justice. It is, therefore, imperative to consistently reassess solutions to racial injustice accepted broadly by White authorities.

Drawing from anti-racist critiques of cultural education as a solution of racial injustice, I argue that privileging curricular integration as a strategy in which to eliminate the racial injustices Indigenous students experience converges with the interests of White citizens. Although this approach has created some change and aligns with advocacy of Indigenous leaders and scholars, the approach also benefits White institutions through, for example, access to funding and employment. Millions of dollars are funneled into institutions in the name of cultural competency, cultural awareness, and decolonization through Indigenous knowledge, land-based, and language programming-funding that ultimately benefits White authorities without causing White distress.

A glaring example of interest convergence occurs at the post-secondary level when departments of educational administration do not require graduate students to complete antiracism policy courses while preparing to become school administrators. In addition, while colleges of education in Canada have identified Indigenization as a priority, teacher candidates who exhibit racism towards Indigenous peoples through their coursework continue to graduate and teach in schools. Teacher educators, particularly Indigenous professors, however, are often reprimanded for poor course evaluations from anonymous racially hostile students (Henry \& Kobayashi, 2017; Mohamed \& Beagan, 2018). Furthermore, the content integration solution aligns with Bell's (1980) interest convergence principle as it suggests inequality can be countered through what $\mathrm{K}-12$ students are taught, as if, somehow, educational inequities will disappear magically once students learn about Indigenous culture, language, history, and experiences with racism. The solution implies that racial justice can be achieved through changing what $\mathrm{K}-12$ students are taught rather than how adults - school authorities - think and act. The solution also misleadingly suggests it is teachers - not school authorities at the highest level - who hold power to change inequitable graduation statistics and academic achievement. Pledges to Indigenization and to teach students about racism, then, in this way and others, converge with the interests of White citizens.

According to the interest convergence principle, and through processes of structural determinism reinforced by essentialist thinking, curricular integration or Indigenization remains a recurring solution to racial injustices because the solution does not infringe on White institutional power. As a result, and as one Métis teacher I interviewed emphasized, "The same issues they are talking about now were there when I graduated in 1986" (P11). It is, therefore, necessary to build on $\mathrm{K}-12$ Indigenous education within integrated provincial schools. For instance, the Métis teachers in my study stressed the following specific practices that disadvantage Indigenous students:

- Racially discriminatory disciplinary actions;

- Racial profiling through academic streaming;

- Inequitable funding practices;

- Racialized hiring and promotion practices; 
- A lack of or imbalance of Indigenous representation and authority;

- A lack of Indigenous and ally leadership in anti-racism education;

- Racially hostile learning environments;

- Racist assumptions about Indigenous parents;

- Teachers' fears of high Indigenous student enrollment schools;

- Informal social and extra-curricular school-based racial segregation;

- Systemic low expectations for Indigenous students; and

- Essentialist beliefs regarding Indigenous histories, perspectives, and identities.

Holding educational authorities accountable to rectify such injustices and shifting approaches when the primary beneficiaries are found not to be the most vulnerable and oppressed Indigenous students is necessary if $\mathrm{K}-12$ schools are to take a comprehensive approach to racial justice.

\section{Conclusion}

Indigenous knowledge systems and languages are inherent rights of Indigenous peoples and protected by federal and international law. The struggle to realize, enact, and safeguard Saskatchewan's Indigenous curricular integration policies within provincial schools, therefore, remains a pressing and consistent challenge. Furthermore, all students can benefit from the rich diversity of Indigenous knowledge systems and languages, and all students deserve to learn about, and how to challenge, colonialism, racism and intersectional oppression. At the same time, as reflected in my conversations with Métis teachers, $\mathrm{K}-12$ authorities require more direct understandings of what racial justice entails beyond curricular integration and the propensity to support Indigenous students in culturally affirming ways. While barriers and resistance to teaching Indigenous knowledge and experiences, as well as anti-racist education, exist, privileging curricular integration as a primary mode of justice within integrated schools neglects the multiple and diverse racialized experiences of Indigenous $\mathrm{K}-12$ students, families, and educators. Like the sacrificed Black schoolchildren in Bell's (1987) fictional story, decades of upholding curricular integration as a primary solution to racial and colonial injustices within Saskatchewan's schools has ensured the "beneficiaries were forgotten long before they were lost" (p. 107). 


\section{References}

Anuik, J. (2010). "In from the margins": Government of Saskatchewan policies to support Métis learning, 1969-1979. Canadian Journal of Native Education, 32, 83-99.

Barron, L. (1990). The CCF and the development of Métis colonies in southern Saskatchewan during the premiership of T.C. Douglas, 1944-1961. The Canadian Journal of Native Studies, 10(2), 243-270.

Bell, D. (1980). Brown v. Board of Education and the interest convergence dilemma. Harvard Law Review, 93(3), 518-533. https://doi.org/10.2307/1340546

Bell, D. (1987). And we are not saved. Basic Books.

Bell, D. (1992). Racial realism. Connecticut Law Review, 24, 363-366.

Bird-Wilson, L. (2011). An institute of our own: A history of the Gabriel Dumont Institute. Gabriel Dumont Institute.

Boeije, H. (2010). Analysis in qualitative research. SAGE.

Buehler, J. (2012). 'There's a problem, and we've got to face it': How staff members wrestled with race in an urban high school. Race Ethnicity and Education, 16(5), 1-24 https://doi.org/10.1080/13613324.2011.646256

Castagno, A. (2008). I don't want to hear that!: Legitimating whiteness through silence in schools. Anthropology and Education Quarterly, 39(3), 314-333. https://doi.org/10.1111/j.1548-1492.2008.00024.x

Castagno, A. E. (2009). Commonsense understandings of equality and social change: A critical race theory analysis of liberalism at Spruce Middle School. International Journal of Qualitative Studies, 22(6), 755-768. https://doi.org/10.1080/09518390903333905

Chandler, P. (2009). Blinded by the White: Social studies and raceless pedagogies. The Journal of Educational Thought, 43(3), 259-288. https://doi.org/10.11575/jet.v43i3.52295

Charmaz, K. (2006). Constructing grounded theory: A practical guide through qualitative analysis. SAGE.

Chartrand, L. (2006). Métis residential school participation: A literature review. In L. Chartrand, T. Logan, \& J. Daniels (Eds.), Métis history and experience and residential schools in Canada (pp. 7-10). Aboriginal Healing Foundation.

Chartrand, L., Logan, T., \& Daniels, J. (2006). Métis history and experience and residential schools in Canada. Aboriginal Healing Foundation.

Comeau, L. (2005). Contemporary productions of colonial identities through liberal discourses of educational reform. Journal of the Canadian Association for Curriculum Studies, 3(2), 925. https://jcacs.journals.yorku.ca/index.php/jcacs/article/view/16974/15776

Delgado, R. (1984). The imperial scholar: Reflections on a review of civil rights literature. University of Pennsylvania Law Review, 132, 561-578. https://doi.org/10.2307/3311882 
Delgado, R., \& Stefancic, J. (2012). Critical race theory: An introduction. New York University Press.

Dixson, A. D., \& Rousseau, C. K. (2005). And we are still not saved: Critical race theory in education ten years later. Race, Ethnicity and Education, 8(1), 7-27. https://doi.org/10.1080/1361332052000340971

Dudziak, M. (1998). Desegregation as a cold war imperative. Stanford Law Review, 41(61), 61120. https://doi.org/10.2307/1228836

Gebhard, A. (2017). Reconciliation or racialization? Contemporary discourses about residential schools in the Canadian Prairies. Canadian Journal of Education, 40(1), 1-30. https://journals.sfu.ca/cje/index.php/cje-rce/article/view/2300

Gillborn, D. (2005). Education policy as an act of white supremacy: whiteness, critical race theory and education reform. Journal of Education Policy, 20(4), 485-505. https://doi.org/10.1080/02680930500132346

Harris, C. (2002). Critical race studies: An introduction. UCLA Law Review, 49(5), 1215-1239.

Henry, F., \& Kobayashi, A. (2017). The everyday world of racialized and Indigenous faculty members in Canadian universities. In, F. Henry, E. Dua, C. E. James,. A. Kobayashi, P. Li, H. Ramos, \& M. S. Smith (Eds.), The equity myth: Racialization and indigeneity at Canadian universities (pp. 115-153). UBC Press.

Hollingworth, L. (2009). Complicated conversations: Exploring race and ideology in an elementary classroom. Urban Education, 44(1), 30-58.

https://doi.org/10.1177/0042085907312496

Irvine, J. J. (1988). An analysis of the problem of the disappearing Black educators. The Elementary School Journal, 88(5), 503-513. https://doi.org/10.1086/461553

Jay, M. (2009). Race-ing through the school day: African American educators' experiences with race and racism in schools. International Journal of Qualitative Studies in Education, 22(6), 671-685. https://doi.org/10.1080/09518390903333855

Kovach, M. (2010). Conversational method in Indigenous research. First Peoples Child and Family Review, 5(1), 40-48. https://fncaringsociety.com/sites/default/files/onlinejournal/vol5num1/Kovach_pp40.pdf

Ladson-Billings, G. (1998). Just what is critical race theory and what's it doing in a nice field like education? International Journal of Qualitative Studies in Education, 11(1), 7-24. https://doi.org/10.1080/095183998236863

Ladson-Billings, G. (2006). It's not the culture of poverty, it's the poverty of culture: The problem with teacher education. Anthropology and Education Quarterly, 37(2), 104-109. https://doi.org/10.1525/aeq.2006.37.2.104

Ladson-Billings, G. (2007). Pushing past the achievement gap: An essay on the language of deficit. The Journal of Negro Education, 3(76), 316-323.

http://www.jstor.org/stable/40034574 
Ladson-Billings, G. (2011). Race...to the top, again: Comments on the genealogy of critical race theory. Connecticut Law Review, 43(5), 1439-1457.

https://opencommons.uconn.edu/law_review/121

Ladson-Billings, G. (2012). Through a glass darkly: The persistence of race in education research and scholarship. Educational Researcher, 41(4), 115-120.

https://doi.org/10.3102/0013189X12440743

Ladson-Billings, G., \& Tate, W. (1995). Toward a critical race theory of education. Teachers College Record, 97(1), 47-68.

Leigh, P. R. (2003). Interest convergence and desegregation in the Ohio valley. Journal of Negro education, 72(3), 269-296.

https://www.researchgate.net/profile/William_Tate/publication/279676094_Toward_a_C ritical_Race_Theory_of_Education/links/569803e908aea2d74375dba0/Toward-aCritical-Race-Theory-of-Education.pdf

Lentin, A. (2005). Replacing 'race', historicizing 'culture' in multiculturalism. Patterns of Prejudice, 39(4), 379-396. https://doi.org/10.1080/00313220500347832

Leonardo, Z. (2014). Education and racism: A primer on issues and dilemmas. Routledge.

Littlejohn, C. (2006). The schooling of First Nations and Métis children in Saskatchewan schools to 1960. In B. Noonan, D. Hallman, \& M. Scharf (Eds.), A history of education in Saskatchewan (pp. 63-85). University of Regina Canadian Plains Research Centre.

Littlejohn, C. (2013). Improving Métis education and employment outcomes: Final report. Métis Nation Saskatchewan.

Lynn, M., \& Jennings, M. E. (2009). Power, politics and critical race pedagogy: A critical race analysis of Black male teachers' pedagogy. Race Ethnicity and Education, 12(2), 173196. https://doi.org/10.1080/13613320902995467

Marshall, C., \& Rossman, G. B. (2011). Designing qualitative research (5th ed.). SAGE.

McCreary, T. (2011). Colour-blind: Discursive repertoires teachers use to story racism and Aboriginality in urban prairie schools. Brock Education, 21(1), 16-33. https://doi.org/10.26522/brocked.v21i1.234

Macdougall, B. (2012). The myth of Métis cultural ambivalence. In N. St-Onge, C. Podruchny, \& B. MacDougall (Eds.), Contours of a people: Métis family, mobility and history (pp. 422-464). University of Oklahoma Press.

Mohamed, T., \& Beagan, B. L. (2018). 'Strange faces' in the academy: Experiences of racialized and Indigenous faculty in Canadian universities. Race Ethnicity and Education. https://doi.org/10.1080/13613324.2018.1511532

Parker, L. (1998). 'Race is ... race ain't': An exploration of the utility of critical race theory in qualitative research in education. International Journal of Qualitative Studies in Education, 11(1), 43-55. https://doi.org/10.1080/095183998236881 
Raptis, H., \& Bowker, S. (2010). Maintaining the illusion of democracy: Policy-making and Aboriginal education in Canada, 1946-1948. Canadian Journal of Educational Administration and Policy, 102, 1-21. https://journalhosting.ucalgary.ca/index.php/cjeap/article/view/42792

Razack, S. (1998). Looking White people in the eye: Gender, race, and culture in the courtrooms and classrooms. University of Toronto Press.

Reid, J., \& Santoro, N. (2006). Cinders in snow? Indigenous teacher identities in formation. Asia-Pacific Journal of Teacher Education, 34(2), 143-160.

Saldana, J. (2009). The coding manual for qualitative researchers. Los Angeles, CA: SAGE.

St. Denis, V. (2004). Real Indians: Cultural revitalization and fundamentalism in Aboriginal education. In C. Schick, J. Jaffe, \& A. Watkinson (Eds.), Contesting fundamentalisms (pp. 37-47). Fernwood Publishing.

St. Denis, V. (2007). Aboriginal education and anti-racist education: Building alliances across cultural and racial identity. Canadian Journal of Education, 30(4), 1068-1092. https://doi.org/10.2307/20466679

St. Denis, V. (2009). Rethinking culture theory in Aboriginal education. In C. Lavine-Rasky (Ed.), Canadian perspectives on the sociology of education (pp. 163-182). Oxford University Press.

St. Denis, V. (2010). A study of Indigenous teachers' professional knowledge and experience in public schools. Canadian Teachers' Federation and Canadian Council on Learning. https://www.oise.utoronto.ca/otso/UserFiles/File/ABORIGINAL_Report2010_EN_Web. pdf

St. Denis, V. (2011). Silencing Aboriginal curricular content and perspectives through multiculturalism: "There are other children here." Review of Education, Pedagogy, and Cultural Studies, 33(4), 306-317. http://dx.doi.org/10.1080/10714413.2011.597638

Stoll, L. C. (2014). Constructing the color-blind classroom: Teachers' perspectives on race and schooling. Race Ethnicity and Education, 17(5), 688-705. https://doi.org/10.1080/13613324.2014.885425

Taeuber, K. (1990). Desegregation of public school districts: Persistence and change. The Phi Delta Kappan, 72(1), 18-24.

Tate, W. F. (1997). Critical race theory and education: History, theory, and implications. Review of Research in Education, 22, 195-247. https://doi.org/10.2307/1167376

Taylor, E. (1999). Critical race theory and interest convergence in the desegregation of higher education. In L. Parker, D. Deyhle, \& S. Villenas (Eds.), Race is ... race isn't: Critical race theory and qualitative studies in education (pp. 181-204). Westview Press.

Truth and Reconciliation Commission of Canada. (2015). Truth and reconciliation commission of Canada: Calls to action. Winnipeg, MB.

http://trc.ca/assets/pdf/Calls_to_Action_English2.pdf 
Vaught, S. E. (2012). 'They might as well be Black': The racialization of Sa'moan high school students. International Journal of Qualitative Studies in Education, 25(5), 557-582. https://doi.org/10.1080/09518398.2010.538746

Van Kirk, S. (1980). Many tender ties: Women in fur trade society, 1670-1870. Watson \& Dwyer

Willinsky, J. (1998). Learning to divide the world: Education at empire's end. University of Minnesota Press.

Yosso, T. J. (2005): Whose culture has capital? A critical race theory discussion of community cultural wealth. Race Ethnicity and Education, 8(1), 69-91. https://doi.org/10.1080/1361332052000341006

Yoon, I. H. (2012). The paradoxical nature of whiteness-at-work in the daily life of schools and teacher communities. Race Ethnicity and Education, 15(5), 1-27. https://doi.org/10.1080/13613324.2011.624506

Young, R. (1995). Colonial desire: Hybridity in theory, culture and race. Routledge.

\footnotetext{
${ }^{1} \mathrm{P}=$ Participant
} 